\title{
THE POTENTIAL OF RELIGIOUS RADICALISM MOVEMENT IN BANYUMAS
}

\author{
RINDHA WIDYANINGSIH ${ }^{1}$, SUMIYEM, KUNTARTO \\ Universitas Jenderal Soedirman
}

\section{Abstract}

Religious radicalism is the trigger for the occurrence of terrorism which is an extraordinary crime and an enemy of all the countries that exist in the world. Since Indonesia as a country has a high vulnerability to religious radicalism, it is important to conduct studies on religious radicalism both nationally and regionally. Knowing the level and potential of religious radicalism is a step for the creation of a comprehensive mechanism of prevention and treatment of religious radicalism. The position of Banyumas as an inter-provincial gateway becomes very strategic for radical groups to spread their ideology and mindset. The ease of inter-regional access underpinned by good supporting facilities and infrastructure is an important point of consideration for radical groups to spread their ideas. Interviews were conducted to obtain data from stakeholders who handle radicalism. the findings were elaborated with supporting literature to provide a more comprehensive result. The results of this study indicate that Banyumas has great potential for the growth and development of religious radicalism, and Banyumas people have high vulnerability to get exposed and influenced by the idea of radicalism caused by factors of religious behavior, geography, culture, technology and information development, and demography. However, so far the level of religious radicalism in Banyumas is still low because there is good cooperation between the stakeholders and the community.

Corresponding author; email: ${ }^{1}$ reindha_84@yahoo.co.id

ISSN 0852-7172 (p) 2461-064X (e)

(C) 2017 Walisongo: Jurnal Penelitian Sosial Keagamaan

http://journal.walisongo.ac.id/index.php/walisongo 
Radikalisme agama merupakan pemicu bagi terjadinya terorisme yang merupakan kejahatan luar biasa dan menjadi musub semua negara yang ada di dunia. Indonesia sebagai negara yang memiliki kerawanan yang tinggi terhadap radikalisme agama penting untuk melakukan kajian-kajian mengenai radikalisme agama baik dalam tingkat nasional maupun regional. Mengetabui tingkat dan potensi radikalisme agama merupakan langkah bagi terciptanya mekanisme pencegahan dan penanganan radikalisme agama yang komprehensif. Posisi Banyumas sebagai pintu gerbang antar provinsi menjadi sangat strategis bagi kelompok-kelompok radikal untuk menyebarkan ideologi dan pola pikirnya. Kemudahan akses antar wilayah yang ditopang dengan kondisi sarana dan prasarana pendukung wilayah yang baik menjadi poin penting pertimbangan bagi kelompok radikal untuk menyebarkan pahamnya. Wawancara dilakukan untuk mendapatkan data dari stakebolder yang menangani radikalisme. Hasil temuan lalu dielabrasi dengan literatur pendukung untuk memberikan gambaran yang lebih komprehensif. Hasil penelitian ini menunjukkan bahwa Banyumas memiliki potensi besar bagi tumbuh dan berkembangnya radikalisme agama, dan masyarakat Banyumas memiliki kerentanan yang tinggi terpapar dan terpengaruh paham radikalisme yang disebabkan karena faktor perilaku beragama, faktor geografis, faktor kultural, faktor perkembangan teknologi dan informasi, serta faktor demografi. Namun demikian sejaub ini tingkat radikalisme agama di Banyumas masih termasuk rendah. Hal tersebut karena adanya kerjasama penanggulangan yang baik antara stakeholder dan masyarakat.

Keywords: Banyumas; religious attitude; religious organization; religious psychology; religious radicalism.

\section{Introduction}

In everyday life, the term "radical" in its use is interpreted as negative because it is always related to terrorism, fundamentalism, and hardliners, although academically it is not always that way. The word "radical" comes from Greek, radiks, which 
means root, that is, something fundamental. The meaning is that everything is sought and understood to the root or essence. In the terminology of Islam, the fundamental thing is tawhid or the basis of Islam. The radical person means the one who understands something, teachings, or problems fundamentally to its roots so that he will hold them firmly to the principle compared to the one who does not understand fundamentally to the roots. Therefore radical understanding actually has a positive meaning. However, today, the term "radical" has shifted in meaning so that radicalism has a negative meaning, and the term "radicalism" is directed to religious groups who make efforts and ways by force to impose a will on the basis of religion.

Geographically Banyumas is a liaison between Central Java and West Java, which according to a study from Lazuardi Birru is an area that has a high index of vulnerability of radicalism. Banyumas lucrative location that is the trade, people, and ideology routes make Banyumas have great potential to be exposed and influenced understanding of radicalism. However, in general, according to interviews with stakeholders, the level of radicalism in Banyumas is still relatively low.

According to police records in Banyumas, there have been cases of the involvement in radicalism and terrorist movements, as evidenced by the existence of cases related to radical organizations such as organization named Gafatar organization or "lone wolf" who are sympathizers of the radical organization. There are also prisoners of terrorism and radicalism cases and former detainees involved in the case of active radicalism and terrorism domiciled in Banyumas. In Banyumas there are also subsidiaries of mass and religious organizations that are nationally considered radical or at least get special attention, but they organize them fairly and do not engage in terror acts that disturb citizens. 
In addition to mass organizations and religious organizations in the community, religious organizations on campus are potentially exposed and influenced by radicalism. Various religious studies that exist in the campus environment is very vulnerable to be infiltrated by radical ideas. The model used is usually through donations for activities. Students feel happy because it helps when they want to hold activities that most cannot be funded by campus. The requested feedback is usually the permissibility of certain $u s t a d z$ to give speech or tausiab but the contents of his tausiah have led to the notion desired by the funder, which is more directed to radical thoughts, such as the election of a regional head that is long, vilifying the government and subtly led to oppose the government, as well as an invitation to defend Islam excessively.

The movement of religious radicalism is a trigger for the emergence of the harmful behavior of terrorism so that it needs comprehensive prevention and handling. Rigid handling by the government against the radical movement does not solve the problem. In fact, it makes the radical movement continuing and causes problems that can trigger new radicalism. When the ruler does not understand the phenomenon of his society, when suspicion and violence are used as a tool to eradicate radicalism, then radicalism will not disappear from historical phenomena. Religious radicalism cannot be resisted by violence (Bakri 2004).

Radicalism that is at the root of terrorism is one of the most extraordinary crimes that become enemies of all countries in the world Therefore, it becomes crucial for Indonesia, which is a Muslim majority country, to conduct a comprehensive mapping of the potentials of the religious radicalism movement and its supporting factors, both in the regions which have been shown to have a high index of radicalism as well as areas of exposure that are prone to exposure to radicalism such as Banyumas. 
Radicalism carried out by a group of Muslims has an ideology (political ideology and religious ideology), and is supported by powerful emotions and religious solidarity. Therefore, it takes persuasive efforts and a sense of brotherhood, so that more radical movements can be prevented again.

Understanding of religious radicalism in the perspective of the psychology of religion, which is the branch of psychology, plays an important role in explaining the motivation of religious violence conducted by individuals who use religion as inspiration. In addition, psycho-social aspects are important things to know to obtain a description of the supporting factors of the occurrence of religious radicalism behavior that determines the high or low potential of religious radicalism in an area.

The first step in this research was to collect information about patterns and attitudes of Banyumas people represented by religious organizations, religious-based mass organizations, religious organizations on campus and religious figures through focus group discussions and interviews. Focus Group Discussion was chosen because they were effective for obtaining large amounts of data in a short period of time and allowing responses from more complete respondents. The tendency of patterns and religious attitudes shown by Banyumas people was checked with stakeholders (intelligence service of Police office) to determine the potential and level of radicalism in Banyumas. The findings were elaborated with supporting literature to obtain more comprehensive data.

Research on radicalism by Lazuardi Birru shows that there are three provinces in Indonesia that are most vulnerable to religious radicalism, namely Aceh Province (56.8), West Java (46.6), and Banten (46.6). The history of the three provinces is based on the discourse of the establishment of an Islamic state, namely GAM (Gerakan Aceh Merdeka) in Aceh, and DI/TII (Darul 
Islam/Tentara Islam Indonesia) in West Java and Banten. This situation indicates that the level of resistance to radical action has not been strong. Similar research is also conducted by Setara Institute which shows the greatest potential of radicalism movement present in big cities (Jakarta, Bogor, Depok, Tangerang, Bekasi and West Java) due to the emergence of the frustrations that happened to the urban society, so that they are potential partners for the fundamentalist movements acting on behalf of Islam. The network of radical organizations succeeds in exploiting the alienation and social frustration conditions of urban society to gather in a religious identity. It is further said that the religious views of the community in Jakarta, Bogor, Depok, Tangerang, and Bekasi show high intolerance. However, this attitude or view cannot be regarded as fundamentalist or radical, but only the potential to increase its attitude to become radical (Yudha 2012).

Similar research was also conducted by Wahid Institute (Muslim 2016) which shows that radical understanding in Indonesia is increasing. Based on the survey results, people who have taken radical action in Indonesia are about 600 thousand people or 0.4 percent of the total population of Indonesia. Therefore if projected in the population, about 600 thousand people with selected respondents have aged over 17 years. According to the Wahid Institution survey, respondents over 17 years of age have the potential to take radical action in the future as they amounted to 7.7 percent of the total population of Indonesia or about 11 million people.

Previously, a survey conducted by the Institute for Islamic Studies and Peace (LaKIP) also showed a similar trend. The survey was conducted in 59 private schools and 41 public schools in 10 regions of Jakarta, Bogor, Depok, Tangerang, and Bekasi. The survey sampled 993 Junior High School students and Se- 
nior High School students. Noteworthy, this survey shows that nearly $50 \%$ of students agreed to violence or radical action for religion. $14.2 \%$ of students said they agree with terrorist acts committed by Imam Samudra, Amrozi, and Noordin M Top. $84.8 \%$ of students also agreed with the enforcement of Islamic Shari'a. Meanwhile, 25.8\% considered that Pancasila is no longer relevant as a state ideology (Rokhma 2012)

\section{Potential and Level of Religious Radicalism in Banyumas}

Southeast Asia has great potential for the threat of radicalism and terrorism. Geographical factors contribute to the spread of radicalism to militant terrorism which is facilitated by the breadth of border areas between countries by land and sea which are the entrance of people, goods and radical understanding itself. The global development that is caused by terrorist attacks in the world and has made countries in the ASEAN region increase domestic awareness. One of the contributing factors is the fact that the area has become one of the international terrorist networks of al-Qaeda and ISIS and their supporters. Countries like Indonesia, Malaysia, Thailand, the Philippines, and to some extent Singapore, have been used as the development of terrorist networking cells and radical Islamic fundamentalist movements (Prasetyo, Panca, and Widodo 2016).

Indonesia's geographical constellation in the cross position of two continents and two oceans, with the world's busiest ALKI (the Indonesian archipelagic sea), is a geostrategic as well as a vulnerable area to the entry of radicalism. With the conditions of an open area and the largest archipelagic country, it is vulnerable to radicalism and terrorism targets for recruitment and training as well as weapons smuggling and personal posts. Indonesia is a country with high vulnerability index of radicalism. A study conducted by Lazuardi Birru (Yudha 2012) shows that 
in 2011 the vulnerability index of Indonesian radicalism was in the range of number 43.6 which means that Indonesia has high vulnerability numbers of radicalism because it is above the safe level threshold that is at number 33.3.

Regardless of the index statistics that are still debated, the empirical fact shows that radicalism is in fact found in everyday life. Radical thinking and the emergence of radical groups that perform various actions and activities that cause unrest and protests from the community are directly in touch with our daily life.

The religious radicalism that is the primary trigger for terrorism is not solely due to personality factors (or any single factor, including poverty or education). In fact, it is a mixture of various political, cultural, economic, socioreligious, demographic and psychological factors. Based on the results of focus group discussion, the writer tries to map the description of the potential of religious radicalism movements in Banyumas shown from the determinant factors as follows:

\section{Religious Behavior Factors}

One's involvement in religious radicalism is heavily influenced by his religious behavior (Khammami 2002). Religion means surrendering to submit to the authority that governs the actions of the birth and the mind. The emergence of religious radicalism (Islam) in Indonesia is suspected by two factors: first, internal factors within the Muslim community itself. This factor occurs because of deviation of religious norms. Secular life in the life of society encourages them to return to the Islamic fundamentalism. This factor is supported by a totalistic (kaffah) and formalistic religious understanding that is rigid in understanding religious texts. The study of religion is only seen from one direction, that is textual, so the action is to refer to the Proph- 
et's behavior literally. The second, is external factors outside of Muslims that support the application of Islamic law in the joints of life.

In general, Banyumas people has a dimension of belief (ideological), and good ritualistic practice and worship. It can be said that the level of religiosity is quite high. This is for example seen from the many places of worship, the splendor of various religious activities both within the community and in the campus environment, and the emergence of various religious organizations and religious studies. Banyumas people is basically open to various currents of thoughts coming from various regions because it is supported by geographical factors.

However, the people of Banyumas are typically not a fanatical society in holding a particular school as there are radical indications found. It is a mere case and shows no common symptoms of Banyumas people's behavior. The dimension of appreciation, practice (consequential), and the dimension of religious (intellectual) religious knowledge are strongly influenced by the social environment and affect the religious behavior resulting from the accumulation of experience. They contribute to determining how the religious model is.

From the various cases of religious radicalism that occurred in Indonesia in general and Banyumas in particular, always shows the tendency of the perpetrators to have extreme religious behavior and tend to deviate. For example, through closed observations, attitudes against the government, to baiat against multinational radical groups such as ISIS. The images displayed through the way they dressed it is nearly same which is identical to the manner of dress and appearance of the Middle East.

Radicalism spread through the enclosed sphere of friendship and is linked to a strong religious flow environment. The spread of radicalism is done through closed studies and conducted in 
places of worship. The mosque is not only a place of worship, but it can also be the locus of exchange of ideas and ideas. Therefore, the mosque can also be a fertile ground for the growth of hard-line ideology.

Someone who often interacts with radical groups either directly or through cyberspace will be very easily influenced radical ideology and have the motivation to do radical action. The dominant influence of the environment will be a kind of legitimacy for actions taken as expected by their environment. Behaving in accordance with environmental expectations is an attempt to get an individual acknowledged in the environment and feel recognized as a part of the environment.

\section{Geographical Factors}

Administratively, Banyumas is located in the Southwest and part of Central Java Province. It is located between East Longitude $108^{\circ} 39^{\prime} 17^{\prime \prime}$ to $109^{\circ} 27^{\prime} 15^{\prime \prime}$ and between the SouthLatitude $7^{\circ} 15^{\prime} 05^{\prime}$ " to $7^{\circ} 37^{\prime} 10^{\prime}$ " which means to be on the southern hemisphere of the equator. The area of Banyumas is about $1,327.60 \mathrm{~km} 2$ or equivalent to $132,759.56 \mathrm{ha}$, with a population of $1,795,844$ inhabitants. The administrative area of the city is divided into 27 districts, 30 subdistricts and 301 villages. The terrain is between land and mountains with mountainous structures and Serayu River for agricultural land, some highlands for settlements and yard, and some mountains for plantations and tropical forests located on the slopes of south Mount Slamet.

Geographically, Banyumas which is located on the strategic path that exists in Java Island and at the same time connecting between West Java Province and Yogyakarta make Banyumas region very potential and prone to spread and grow radical understanding. For example the supporters and participants of the radical Gafatar organization have many supporters from 
Banyumas, and even the perpetrators or participants involved in the case of transnational network terrorism have been captured with Banyumas locus.

The position of Banyumas as an inter-provincial gateway becomes very strategic for radical groups to spread their ideology and mindset. The ease of inter-regional access underpinned by good supporting facilities and infrastructure is an important point of consideration for radical groups to spread their ideas.

The location of Banyumas adjacent to Cilacap Regency where there is Nusakambangan Prison which becomes central for detention house of convicted terrorist case gives much impact to the growth and development of religious radicalism. In the Banyumas resort police record, perpetrators of religious radicalism in Banyumas have been recorded visiting inmates of terrorism cases in Nusakambangan Prison although they have no blood relation or friendship with the previous convict. Even there was a case of sirri (secret) marriage between a sympathizer with an inmate of terrorism case which was done by taaruf process (introduced through Islamic forum which s/he followed). This indicates that the process of propagating religious radicalism can still be done from behind the cells of detention or at least the sympathizers of religious radicalism movements do not disappear after their leader is imprisoned.

\section{Cultural Factors}

Banyumas people is known as an egalitarian and open society and uphold the relationships between individuals. This is evident from the use of everyday language styles that do not really care about social levels. The egalitarian nature makes the relationship worth it. With a cablaka style or the way it is, it is capable of removing the structural barriers and making it a communal society. 
The egalitarian symbol of Banyumas people is seen in the symbol of Punakawan Carub Bawor explaining that Banyumas people are open in everyday life called cablaka or blakasuta. Bawor character is a typical icon of Banyumas because of the resemblance of Banyumas character with Bawor character. Other puppet figures who also show character and egalitarian character can be found in such figures as Lingsanggeni, Antasena, Werkudara, and the panakawan in the show of leather puppet gagrag Banyumasan.

Banyumas people are very familiar with the presence of immigrants. Two causes of the large number of immigrants from outside Banyumas are the presence of universities and high schools that have students from various regions as well as the large number of job seekers from outside Banyumas because of good economic growth in Banyumas which is the third largest city in Central Java. The openness of society also appears in the acceptance of foreigners as well as new understandings that have never been known before. The Banyumas people characteristic makes radical members easy to enter and mingle with the community.

The presence of various universities in the Banyumas region contributes significantly to the large number of immigrants entering Banyumas. The presence of the newcomers makes Banyumas people familiar with new people and not easily suspicious with the presence of foreigners. This is one of the carrying capacity for radical groups in the process of recruitment and increasing the existence of the group.

In the case of Gafatar organization, for example, this group received many supporters from Banyumas people by using a cultural approach. The gafatar organization is able to exploit the egalitarian and open nature of Banyumas society as a gateway to the minds of Banyumas people. Evidently this group has many 
militant supporters who come from Banyumas.

The action of Gafatar organization was initially socially responsible for the sympathy of the Banyumas people, for example by conducting various actions and social activities, blood donations, youth competitions, providing assistance to the poor and orphans and other social activities. The gafatar organization even gained support from the local government and the military before it was considered a radical group trying to change the state ideology. The combination of community characteristics and social activities close to the community is a powerful formula for capturing the masses to make them join Gafatar organization.

\section{Technology and Information Development Factors}

In Indonesia, every year the number of internet users is growing very rapidly. Research report of the Association of Internet Service Providers Indonesia (APJII) with Center for Communication Studies (Pusakom) the University of Indonesia in 2014 reported, that the growth of the number of internet users in the country has continued to increase since 2005. If in ten years ago there are 16 million people who used the internet, in 2014 it increases to 88,1 million netizens $(34.9 \%$ of the total Indonesian population of 252.4 million people). Judging from the age of netizens, the research explains, that as much as $49 \%$ or nearly half are aged 18 to 25 years. Meanwhile, their education level is $64.7 \%$ of senior high school graduates. A total of 875 netizens claimed to use social media when connected to the internet, while 68.7\% for searching and browsing (Muthohirin 2016).

From the various cases of radicalism and terrorism revealed, most use the Internet as a medium of communication and consolidation of the movement. In the case of Ibnu Dar, who attacked Police Office of Banyumas Regency, sympathizers of this radi- 
cal group obtained information via the Internet about ISIS and radical movements against the ruling government. From various information through the internet, this then gives inspiration for the perpetrator to perform an action which he considered as part of jihad (Islamic action). The ease of obtaining information through the Internet related to movements and radical groups is difficult to control, though not necessarily non-business, for example by the blocking of sites that are considered to bring radicalism and terrorism are troubling. Ibnu Dar's case is not the only one and the last one. In the bigger case, such as the bombing case, the technological factor has a very important and decisive role. The chain of command of the radicalism movement also utilizes information technology although the communication system used usually uses a disconnected cell system. This means that these radical movements are performed on small groups and between groups are usually not directly related so that their existence will not be easily traced.

The group's internal communication nowadays also uses social media a lot, for example using the application Whatsapp, BBM, Line, and so on. Social media that is private, easy, cheap, and can be reached across the globe allows communication to be effective and difficult to be tracked by people outside of group members. The result of the interview with the Intelligence of Polres Banyumas stated that, in the profile picture of social media, people who have been involved in the case of radicalism or suspected person can be used as one of the means to perform tracking and monitoring.

Based on the results of interviews with intelligence chiefs obtained the fact that radical groups and terrorists use social media in communicating and uses a disconnected cell communication system, they also typically use fake identities and often change cell phone numbers to make it difficult to trace. the intelligence 
service oversees the profile picture displayed in social media accounts of radical suspected or ex-terrorist prisoners.

The development of information technology is able to produce information access quickly, intensely, massively, and has a broad spectrum and can be accessed in bulk. The fast-paced and sophisticated digital era has empirically been able to become a real force capable of bringing the solidarity, emotions, and militancy of radical groups across countries and across continents. Their presence on virtual networks has changed the pattern and strategy of their movement. An easy, inexpensive, and effective way to further strengthen the network and facilitate member recruitment. The presence of social media such as Facebook, YouTube, Twitter, blogs to free messaging services like WhatsApp, Line, BBM, etc. is a new way for radical groups to communicate and consolidate the movement.

Wiktorowicz and Amanullah (2015) concluded that terrorist groups and radical organizations, especially ISIS, have strengthened their ability to use social media and other virtual networks to expand their networks and support globally, and to access funding sources, massive recruitment and new political mainstream propaganda beyond the limits that governments and communities in society can afford. This shows that social media has become one of the strategic instruments used by terrorist and radical groups to strengthen its operations on a global scale.

The findings are reinforced by Michelle Hughes and Michael Miklaucic (Nasution 2017) explaining that the use of virtual networks, such as social media as an instrument of online radicalization and recruitment, will generate sympathy from individuals who feel conditions that can rise solidarity, such as poverty, social inequality, and political frustration. These individuals will be moved to improve their access to sites, chat rooms, online journals, streaming propaganda videos, and other online media. 
This sympathy may develop into support when the intensity of online access continues and the more intimate relationships with other individuals or groups (feelings of in-group) that share a common base of solidarity and sympathy for radical and terrorist groups exist. This support can be in the form of donations, personnel resources, as well as the security networks necessary for the development of radical movements.

\section{Demographic Factors}

Judging from the demographic composition that exists in Banyumas, young people who are the most vulnerable age group to the dangers of radicalism, have a considerable proportion. Categorization of who can be called as youth contained in Law Number 40 of 2009 on Youth. Although in the law mentioned that the youth are those aged 16-30 years but until now it does not matter if youth organization is led by those aged well over 30 years, even over 40 years. Based on the age limit of youth categorization based on Law Number 40 of 2009 the number of Banyumas population classified as young age is 474.317 people based on Banyumas Statistics Central Agency data in 2014. If the population of Banyumas amounted to 1.620.918, it means that the population classified as young people occupy $29.26 \%$ or one-third of the total population of Banyumas. This number does not include young people who are immigrants from school or work in Banyumas. Noted there are 93 Senior High School and 27 Universities and the students not only come from Banyumas but also from other cities in Indonesia. This means Banyumas has great young potential.

With the large number of young people in Banyumas, then the great potential for the spread of radicalism in the younger generation exists. In many studies: (Azca 2013), (Qodir 2014), (Sukabdi 2013), and (Muljajdi 2015) it is mentioned that young 
people are very vulnerable age groups exposed to and affected by radicalism. Studies at the Maarif Institute, for example, released that since the last few years the movement of radicalism has entered the world of education and among youth. The phenomenon of suicide bombings, bombs in Serpong, and a network of NII (Islamic State of Indonesia) some time ago confirmed that the radical movement infiltrate and expand the reach of its network through campus and school. Students who are still in the process of identifying themselves and learning stages are the most strategic targets for strengthening the movement of religious radicalism. Moreover, the strategic position of students, who have broad social and relatively autonomous reaches, is considered by radical movements as the most appropriate and easy means to proliferate the radical ideologies they strive for. The findings of (Darraz 2103) also reinforce the magnitude of the potential of young people affected by the idea of radicalism. Darraz reviewed the practice of radicalization in public education institutions in public high school level. This radicalization occurred through the process of learning and extracurricular activities that exist in schools. The lack of Islamic discourse among students and some teachers made them very open to accepting the radical ideologies exhaled without critical filtration (Fanani 2013).

The facts about the vulnerability of young people and the penetration of radicalism mentioned above, are further strengthened with the latest research results of the Maarif Institute. In the 2011 study, the Maarif Institute tried to investigate the mapping of radicalism issues among high school students in $50 \mathrm{Se}-$ nior High School in four cities; Cianjur, Pandeglang, Surakarta, and Yogyakarta. The Maarif Institute found that young people or students today have a tendency to internalize radical views that are closely watched by their immediate environment. The 
findings in the mapping research conducted by Maarif Institute in some respects reinforce some previous research on the radicalism targeting young people, especially high school students. Even so with SETARA Institute which in June 2008 conducted a survey on the Young Generation View of Nationality, Plurality and National Leadership. Which in the survey, the symptoms of religious fundamentalization on the younger generation were measured through agreement on the presence of a regionally based religious rule, at least $56.1 \%$ agreed. While $36.2 \%$ stated disagreed. This is certainly the concern of all parties, especially those who believe that religious fundamentalism is the initial symptom for a religious view which in some degree becomes justified for intolerant action by using religious arguments $(\mathrm{Mu}-$ hammad and Pribadi 2013).

School and campus environments are an easy target for radical groups to spread their ideological wings and gain the support of educated young people. It is important to remember that the perpetrators of radicalism and terrorism are largely intelligent and have the excellent academic background, such as Dr. Azhari, Imam Samudra, Santoso, Daengkoro, etc. (Supian 2016).

The vulnerability of youth to radicalism in Banyumas also shows that the perpetrators involved in the radicalism movement, the case of radicalism and terrorism, and the supporters of the radical movement belong to the youth category. Like the radicalism movement mode elsewhere, radical ideologies are disseminated through religious forums, both in the social and educational environment, which means that the movement pattern is quite open, and of course the exclusive, underground and closed organizations.

The spread of radical understanding among young people is also quite prevalent in schools and campuses. High School and Higher Education in Banyumas become very vulnerable to 
the spread of radical understanding that infiltrates smoothly through religious extracurricular activities. Mosques in schools and campuses are often used as a means and place for study which are slowly led to radicalism. For example, Hizbut Tahrir Indonesia has many supporters who come from among students in Banyumas and regularly perform religious activities and event sponsor for religious activities so get sympathy from the young people.

\section{The Influence of Religious Behavior with Involvement of Reli- gious Radicalism}

Radicalism is considered a movement of extremism and exclusivism. The movement that lies behind it is suitable to be associated with terrorism and always a political background underlying such views. The linkage between religion and politics can even be traced back to medieval times. Religious excuses are widely used to achieve certain political interests. Religion became one of the many entities used to increase the popularity and attention and support of audiences because religion is a sensitive matter that concerns the intrinsic in a person.

Religion is a set of value systems in the form of validation and justification in regulating individual and community attitudes. In a religious society, religion infiltrated into social activities, both economic, political, familial, and recreational. At this level religion has played a role in the background of movements that occur in society. In the case of religious radicalism is considered very appropriate to appear as the main cause and directly linked with certain figures and groups.

Belief is the fundamental and deepest thing of the human and related to the principles of religious teachings that emphasize holiness. In such conditions, reason will lose its function. People will be easy to believe and accept whatever teachings are 
given without criticism. As a side of the inner life of the most in the value system adopted plays a very important role and be a role model. Values that are believed to be considered truths contribute to solidarity and do not hesitate to sacrifice lives. In this case, religious symbols become the trigger of a mass movement, including radicalism and terrorism.

Religious behavior is strongly influenced by internal factors (heredity, age, personality, and psychological condition) and external factors (family, institution, and community). The combination of these internal and external factors influences a person deeply in the way religious and religious views are displayed (Jalaluddin 2016).

Internal factors in the form of heredity, age, and personality play a role in the way a person's religion and maturity but not necessarily affect the behavior of one's religious. A child born from a terrorist parent will not necessarily inherit a terrorist tendency to his or her child. Religious behavior is not an element that can be inherited through chromosomes or blood cells so there is no guarantee that religious attitudes and behavior are influenced by genetic elements.

Religious behavior is not always related to age. The radicals and terrorists are known to come from a wide range of age ranges. The more mature a person does not always affect the level of the religious and religious way of a person. Similarly, with personality, it does not have a direct relationship with one's religious behavior. The personality of a person gives an idea of the trends of one's behavior patterns but there is no relation to radical religious behavior associated with a particular personality type. Involvement in radicalism and terrorism in various studies mentioned is not identical with certain personality types because the sympathizers of the radical movement can come from any type of personality. 
External factors such as environment, institutions, and society have a big role in determining the religious behavior of a person. External factors will affect the way of the view of religion, and behave in accordance with the social demands desired by the environment. Behavioral does not happen by itself, but the formation of behavior always takes place in human interaction and with respect to certain objects. Social interactions within the group as well as outside the group can change behavior or made new behaviors such as social media, newspapers, radio, television, books, and so on. External factors associated with the interaction of a person with his environment gives a significant impact on religious behavior, religious teachings, and how to behave in everyday life. The idea of radicalism will easily enter and influence a person depending on the environment of a person interacting. The influence of reading books, social media, and the internet as well as the social environment will greatly influence the way and behavior of religion.

\section{Discussion}

In religious societies like in Indonesia, religion infiltrated into various social activities, such as economic, political, familial, even recreational. The value of religion has played a role in the background of the various movements that occur in society. Religious symbols are more easily portrayed as triggers of a mass movement (Jalaluddin 2016). The value system adopted by a person or group of people is closely related to a religion that is inner life. Value is something that is assumed to be true and must be maintained, sometimes up to the sacrifice of life, is believed to be able to generate strong solidarity, as seen in the case of radicalism and terrorism, although it can not be denied that religious radicalism is inseparable from the legitimacy of religion and the supremacy of the political forces behind it. 
The case of radicalism or people indicated to have an affiliation with radicalism groups or supporters/sympathizers of the individual radicalism movement (lone wolf) were found in Banyumas. The last case related to the sympathizers of the radicalism movement was the attack in Banyumas Police office on 11 April 2017 by a young man from Purbalingga known as Ibnu Dar. The attack was carried out by bumping his bike and carrying out attacks with sharp weapons to injure the police. Ibnu Dar was a well-known ISIS sympathizer from various books and ISIS attributes found in his home.

In addition to sympathizers of radical movements that are multinational like ISIS, supporters of radical movements that have operating areas in Indonesia are also found in Banyumas, such as Gafatar and Hizbut Thahrir Indonesia. According to the Banyumas Police office record, 24 Banyumas residents are known to have joined Gafatar group (ex-Gafatar), consisting of 11 people who deliberately moved and sold their houses in Banyumas to join Gafatar. While 13 other people have Banyumas Identity card but work outside the region. In addition to the sympathizers of radical movements, some of the inmates involved in the case of radicalism and terrorism are known to originate from Banyumas or have lived in Banyumas Regency. This indicates that Banyumas regency is one of the targeted areas for the spread of radical groups to disseminate its ideas and to recruit members.

The mass organizations and religious organizations in Banyumas District are locally or only available in Banyumas and some are subsidiaries of the central organization. The various activities undertaken are usually typical of the regional and not always in line with the central organizational agenda. For example, when the Front Pembela Islam in Jakarta takes a sweeping action of a restaurant that opens at noon in Ramadhan, the same 
thing does not happen or not done in Banyumas. The movement of same organization is not necessarily the same, meaning that if an organization is considered radical at the central level then the same organization at the regional level can not automatically be considered radical as well, because the same organization at the regional level does not do as much as the organization at the central level. So far, the Banyumas Police are doing monitoring and coaching. Another example is when the Ahmadiyah group which is in some areas considered a heresy, but in Banyumas does not get resistance and can coexist with the surrounding community.

In an organization or a radical group itself, there is a kind of rejection with a radical label attached to their group. In their point of view, they obey the scriptures authentic Hadith. The radical label attached to them is believed to be just a conspiracy in order to discredit and destroy Muslims who want to stick to the principles laid down in Holy Quran and Hadith.

The difficulties of radicalism measurements are caused: First, officially registered Organizations generally exhibit normative attitudes and expressions that are not necessarily representative of the truth. This is seen in the Focus Group Discussion forum conducted in this study, that religious organization is allegedly observed, and often reported to have an intersection with the idea of radicalism, in fact giving statements of attitude that is normative and reject the notion of radicalism. Similar attitudes are also evident when organizations are confronted with stakeholders, so interviews with stakeholders that are outsourced are not much different. There is a reluctance to show the attitude of these organizations in a real way. This is a kind of self-protection in order to avoid a radical label that would complicate their actions and activities, but that does not mean that stakeholders, especially police, do not supervise. 
Second, the radical movement is generally carried out by organizations and groups that are closed and secretly. The recruitment system is based on a friendship background and uses a disconnected cell communication system, they also typically use fake identities and often change cell phone numbers to make it difficult to trace. Communication systems built by organizations that support or affiliate with radicalism and terrorism movements are using disconnected cell systems. The mechanism used is to form small groups/cells and communicate with private networks that are private and often use fake identities or use fictitious names that are difficult to trace, unless someone reports or informs them. Thoughts of dissemination of thought, doctrine, and action plan are done in one group/cell, and there is no coordination or communication between groups/cells, that is why it is called a disconnected cell system.

Religious radicalism in Banyumas is influenced by psychosocial conditions that can not be separated from global conditions. The location of Banyumas, which connects the central point in Java Island and close to the Nusakambangan Prison inhabited by the inmates of terrorism, has an impact on the spread of radical ideas that are still being disseminated by supporters and militant participants. The open community (cablaka) supported by an open and strategic area makes Banyumas have a lot of targets for the radical group to do for the next leadership and spread of radical understanding.

It is interesting to note that Banyumas with the potency of great religious radicalism has even recorded several times the case of religious radicalism emerged in Banyumas, but so far the level of radicalism in Banyumas is low. The open and egalitarian nature of the Banyumas people fosters a sense of community that enhances communal cohesiveness. The openness of Banyumas people apart from being a threat turns out to be a distinct 
advantage because with an egalitarian openness, it turns out to be a great social capital. There is a strong shared awareness in preventing and overcoming the radical ideologies that enter Banyumas region. Social capital owned so far can be a shield that dispels the radical understandings. In addition, cooperative attitude with related institutions is shown by Banyumas people if there is suspicion related to radical understanding, that is, there will be reporting system from the lowest level government authorities in the village.

\section{Conclusion}

Banyumas has great potential for the emergence of religious radicalism movements. Banyumas people have high vulnerability to radical understanding caused by behavioral factors of religion, geography, culture, technology and information development, and demography.

The level of radicalism in Banyumas is low but not sterile from radicalism because, according to police records in Banyumas, there have been cases of the involvement of radicalism and terrorism movements, as evidenced by the existence of cases related to radical organizations such as Gafatar organization or Lone Wolf who are sympathizers of the radical organization. There are also prisoners of terrorism and radicalism cases and former detainees involved in the case of active radicalism and terrorism domiciled in Banyumas. In Banyumas, there are also subsidiaries of mass and religious organizations that are nationally considered radical, or at least get special attention. However, they organize their activities fairly and do not engage in terror acts that disturb citizens.

In Banyumas, there are also several cases of religious radicalism, prisoners of radicalism and ex-radicalism member, but so far the level of the religious radicalism of the city is relatively 
low. This is because of the better role of the stakeholders and the community who together fight against religious radicalism. It is important to do further research on the level of religious radicalism by using the radicalism index approach to provide a more comprehensive picture, so as to be able to formulate a policy of radicalism prevention (anti radicalism), as well as deradicalization efforts by promoting the aspect of locality to run the policy effectively.

\section{Bibliography}

Azca, Muhammad Najib. 2013. "Yang Muda Yang Radikal Refleksi Sosiologis Terhadap Fenomena Radikalisme Kaum Muda Muslim Di Indonesia Pasca Orde Baru." Jurnal Maarif 8 (1).

Bakri, Syamsul. 2004. "Islam Dan Wacana Radikalisme Agama Kontemporer.” Jurnal Dinika 3 (1): 1-19.

Darraz, Muhammad Abdullah. 2103. "Radikalisme Dan Lemahnya Peran Pendidikan Kewargaan.” Jurnal Maarif 8 (1): 154-73.

Fanani, Ahmad Fuad. 2013. "Fenomena Radikalisme Di Kalangan Kaum Muda.” Jurnal Maarif 8 (1): 4-13.

Jalaluddin. 2016. Psikologi Agama, Memahami Perilaku Dengan Mengaplikasikan Prinsip-Prinsip Psikologi. Jakarta: Raja Grafindo.

Khammami, Zada. 2002. Islam Radikal, Pergulatan Ormas-Ormas Islam Garis Keras Di Indonesia. Jakarta: Teraju.

Muhammad, Wahyudi Akmaliah, and Khelmy K. Pribadi. 2013. “Anak Muda, Radikalisme, Dan Budaya Populer.” Jurnal Maarif 8 (1): 132-53. 
Muljajdi, Yusar. 2015. "Perlawanan Kaum Muda Terhadap Hegemoni Radikalisme Agama Dalam Bentuk-Bentuk Budaya Populer." Jurnal Mamangan 22 (1): 73-88.

Muslim, Ikhlasul Amal. 2016. "Gerakan Situs Radikalisme Dan Sosial Media.” https://www.ipnu.or.id/gerakan-situs-radikalisme-dan-sosial-media/.

Muthohirin. 2016. "Mewaspadai Radikalisme Islam Di Media Sosial I GEOTIMES.” https://geotimes.co.id/kolom/mewaspadai-radikalisme-islam-di-media-sosial/.

Nasution, Wildan. 2017. “Menangkal Radikalisme Di Media Sosial.” http://theglobal-review.com/lama/content_detail. php?lang=id\&id=19894\&type $=2$.

Prasetyo, Dedi, R. Z. Panca, and Urip Widodo. 2016. Ilmu Dan Teknologi Kepolisian: Implementasi Penanggulangan Terorisme Dan Radikalisme Di Indonesia. Jakarta: Raja Grafindo.

Qodir, Zuly. 2014. Radikalisme Agama Di Indonesia. Yogyakarta: Pustaka Pelajar.

Sukabdi, Zora. 2013. "Kaum Muda Dan Radikalisme (?).” Jurnal Maarif 8 (1): 132-53.

Supian. 2016. "Eksklusivitas Kegiatan Keagamaan Mahasiswa (ROHIS) Di PTU: Bibit-Bibit Radikalisme?”

Wiktorowicz, Quintan, and Shahed Amanullah. 2015. "How Tech Can Fight Extremism.” CNN. http://edition.cnn. com/2015/02/16/opinion/wiktorowicz-tech-fighting-extremism/index.html.

Yudha, Sakti Wira. 2012. "Radikalisme Kelompok Islam Analisis Struktur Agen Terhadap Wacana Kelompok Islam Pasca Orde Baru.” Universitas Indonesia. 
This page intentionally left blank 